\title{
Markov Switching and the Taylor Principle
}

\author{
Christian J. Murray \\ University of Houston
}

\author{
David H. Papell \\ University of Houston
}

\author{
Alex Nikolsko-Rzhevskyy \\ Lehigh University
}

August 5, 2013

\begin{abstract}
Early research on the Taylor rule typically divided the data exogenously into pre-Volcker and VolckerGreenspan subsamples. We contribute to the recent trend of endogenizing changes in monetary policy by estimating a real-time forward-looking Taylor rule with endogenous Markov switching coefficients and variance. The response of the interest rate to inflation is regime dependent, with the pre and post-Volcker samples containing monetary regimes where the Fed did and did not follow the Taylor principle. While the Fed consistently adhered to the Taylor principle before 1973 and after 1984, it followed the Taylor principle from 1975-1979 and did not follow the Taylor principle from 1980-1984. We also find that the Fed only responded to real economic activity during the states in which the Taylor principle held. Our results are consistent with the idea that exogenously dividing postwar monetary policy into pre-Volcker and post-Volcker samples misleading. The greatest qualitative difference between our results and recent research employing time varying parameters is that we find that the Fed did not adhere to the Taylor Principle during most of Paul Volcker's tenure, a finding which accords with the historical record of monetary policy.
\end{abstract}

Correspondence:

Department of Economics, University of Houston, Houston, TX 77204-5019

Chris Murray, Tel: (713) 743-3835, Fax: (713) 743-3798, e-mail: cjmurray@uh.edu

Alex Nikolsko-Rzhevskyy, Tel: (901) 678-4627, e-mail: alex.rzhevskyy@ gmail.com

David Papell, Tel: (713) 743-3807, Fax: (713) 743-3798, e-mail: dpapell@uh.edu

We thank seminar participants at the University of Alabama, University of Cincinnati, University of Washington, the Federal Reserve Bank of Dallas, the Federal Reserve Bank of St. Louis, Texas Econometrics Camp XI, the $14^{\text {th }}$ Annual Symposium of the SNDE, the Conference in Honor of Charles Nelson, the Editor, and an anonymous referee for comments and suggestions. We are grateful to Dean Croushore, Athanasios Orphanides and Glenn Rudebusch for providing their data, and to Ming Lo for providing his Gauss code. 


\section{Introduction}

The Taylor principle, that the Fed and other central banks should increase the nominal interest rate more than point-for-point with inflation, so that the real interest rate increases when inflation rises, has become a central tenet of monetary policy. As exemplified by Greenspan (2004), the Fed explicitly recognizes that satisfying the Taylor principle is necessary for achieving its mandate of stabilizing inflation independent of whether or not it follows a particular policy rule.

While there is an extensive literature on whether or not the Taylor principle holds during different periods, early research on the subject typically made the choice of sub-samples exogenously, usually to correspond with the tenure of various Federal Reserve Chairmen. Taylor (1999) estimates rules over the 1960:1 - 1979:4 (pre-Volcker) and 1987:1 - 1997:3 (Greenspan) periods, and finds that the coefficient on inflation is greater than unity, so that the Taylor principle holds, only in the latter period. Clarida, Gali, and Gertler (2000) divide their sample into the 1960:1 - 1979:2 (pre-Volcker) and 1979:3 - 1996:4 (Volcker-Greenspan) periods, and also find that the Taylor principle holds only in the latter period. Their results are robust to various measures of the output gap and to excluding the first three years of the Volcker regime.

While the initial research on Taylor rule estimation used revised data, following the work of Orphanides (2001) it has become standard practice to use real-time data that was available to policymakers at the time that interest-rate-setting decisions were made. Orphanides (2004), using real-time data, estimates Taylor rules for the 1965:4 - 1979:2 (pre-Volcker) and 1979:3 - 1995:4 (Volcker-Greenspan) periods. In contrast to earlier research with revised data, he finds that there was no significant difference in the interest rate response to inflation between the pre-Volcker and Volcker-Greenspan periods, with the Taylor principle being satisfied during both periods. In 
addition, he finds that the interest rate responded to the output gap during the pre-Volcker, but not the Volcker-Greenspan, periods. Thus, while they differ on their characterization of the conduct of monetary policy, Taylor (1999), Clarida, Gali, and Gertler (2000), and Orphanides (2004) all explicitly divide the sample by the tenure of the Fed Chairmen.

More recent research has questioned both this exogenous choice of subsamples and the characterization of the conduct of monetary policy as pre-Volcker and Volcker-Greenspan. Boivin (2006) uses real-time data to estimate a forward-looking Taylor rule with time-varying coefficients. He finds that the Fed's response to forecasted inflation was strong until 1974, fell in the second half of the 1970s (perhaps not satisfying the Taylor principle), and strengthened between 1980 and 1982. The response to real economic activity weakened throughout the 1970s and, from the mid-1980s on, responded strongly to inflation and weakly to real activity. Kim and Nelson (2006) also estimate forward-looking Taylor rules with time varying coefficients, using ex-post data. ${ }^{1}$ Their empirical results suggest that the conduct of monetary policy since 1970 can be divided into three periods: 1970s, the 1980s, and the 1990s. Davig and Leeper $(2006,2011)$ estimate a Markov-Switching Taylor Rule with ex-post data beginning in 1948, which they imbed in a calibrated New Keynesian DSGE model. Their model has four states: active monetary policy (satisfying the Taylor principle) with low and high variance errors, and passive monetary policy with low and high variance errors. They find that monetary policy is passive from 19481979 and active afterward except from 1991-1994 and 2001 to the present., ${ }^{2,3}$

\footnotetext{
${ }^{1}$ The endogeneity induced by using ex-post data is corrected by using a Heckman type two-step estimator.

${ }^{2}$ Favero and Monacelli (2005) estimate two-state Markov switching models for the pre-Volcker and VolckerGreenspan periods. While they find evidence of two monetary regimes in each period, the Taylor principle is satisfied in neither state for the pre-Volcker period and in one of the states for the Volcker-Greenspan period. ${ }^{3}$ Alcidi et al. (2011) consider deviations from a linear Taylor rule during the Greenspan era by estimating a logistic smooth transition model. They find that a linear Taylor rule fails to detect important changes in the Fed's stance in response to the financial crisis of 2001 and the risk of hitting the zero lower bound in 2002-2003. Although they do not work with a Taylor rule, Owyang and Ramey (2004) estimate a Markov Switching model of
} 
The results contained in these studies suggest that each pre and post-Volcker subsample contains more than one monetary regime. Indeed, Kim and Nelson (2006) write, "The conventional division of the sample into pre-Volcker and Volcker-Greenspan periods could mislead the empirical assessment of monetary policy." We contribute to this debate by estimating a Markov switching model for a forward looking Taylor rule, utilizing various real-time inflation forecasts and measures of the output gap. The data begins in 1965:4, the earliest date for which the real-time data are available, and ends in 2007:4 at the start of the Great Recession. We find evidence of two separate regimes, where the Fed follows the Taylor principle in one state, but not the other. The estimated dates for the Taylor principle state are 1965:4 - 1972:4, 1975:1 1979:3, and 1985:2 - 2007:4. In addition, the coefficient on the output gap is only significant in the stable Taylor rule state.

A seemingly anomalous result is that, with the exception of 1973:1 to 1975:1, we estimate that the Taylor principle held during almost all of the Great Inflation. This is in accordance with Orphanides (2004), who shows that, using a forward-looking model with inflation forecasts, the Taylor principle holds for the 1970s. In contrast, Nelson (2005) and Nikolsko-Rzhevskyy and Papell (2011) show that, when actual inflation rates are used, the Taylor principle does not hold for the same period. None of these papers, however, chooses the sample period endogenously.

A major theme of this paper is that, by using Markov switching methods, we are able to choose policy regimes endogenously rather than impose regimes exogenously based on different Federal Reserve chairmanships. A direct comparison of our results is with Orphanides (2004) who, using real-time data, finds that the Taylor principle held in both the pre-Volcker and the

inflation/unemployment policy tradeoffs which finds policy episodes initiated by switches to more accommodating regimes that Granger-cause NBER recessions. 
Volcker-Greenspan periods. When the break date is endogenized by Markov regime switching, each of Orphanides' regimes contains periods where the Fed both followed and did not follow the Taylor principle. Another comparison is with the time varying parameter results of Boivin (2006) and Kim and Nelson (2006). While our regimes do not correspond exactly with their time-varying coefficients, our results on the monetary policy response to inflation are more congruent than with Orphanides (2004), who finds that the Taylor principle has held consistently since 1965 . Our results on the monetary policy response to real economic activity, in contrast, do not accord with Orphanides (2004), Boivin (2006), or Kim and Nelson (2006). Specifically, Boivin (2006) and Kim and Nelson (2006) find a change toward following a stabilizing Taylor rule in 1980, whereas we estimate that this did not occur until mid 1985.

\section{A Markov Switching Model for the Taylor Rule}

Following Taylor (1993), the monetary policy rule postulated to be followed by the Fed is

$$
r_{t}^{*}=\pi_{t}+\delta\left(\pi_{t}-\pi^{*}\right)+\omega \hat{y}_{t}+R^{*}
$$

where $r_{t}^{*}$ is the short-term nominal interest rate target (Federal Funds Rate), $\pi_{t}$ is the inflation rate, $\pi^{*}$ is the target level of inflation (usually considered equal to $2 \%$ ), $\hat{y}_{t}$ is the percentage deviation of output from its long run trend (the output gap), and $R^{*}$ is the equilibrium level of the real interest rate (also usually considered equal to $2 \%$ ).

According to the Taylor rule, the Fed raises the nominal interest rate if inflation rises above its target and/or if output is above potential output, and lowers the nominal interest rate if inflation falls below its target and/or if output is below potential output. The target level of output deviation from long run trend $\hat{y}_{t}$ is 0 because, according to the natural rate hypothesis, output cannot be permanently raised above potential. The target level for inflation is positive because it is generally believed that deflation is much worse for an economy than low inflation. 
The parameters $\pi^{*}$ and $R^{*}$ can be combined into one constant term, which leads to the following equation,

$$
r_{t}^{*}=\mu+(1+\delta) \pi_{t}+\omega \hat{y}_{t}
$$

The condition $(1+\delta)>1$, known as the Taylor principle, states that, when inflation rises above target, the Fed raises the nominal interest rate by more than point-for-point, so that the real interest rate rises. This has been emphasized by Taylor as the crucial condition for economic stability. Two aspects of the Taylor principle are worth noting. First, according to Taylor's (1993) original formulation, $\delta=\omega=0.5$, so that the Taylor principle is automatically satisfied by the Taylor rule. Second, as emphasized by Greenspan (2004), the Taylor principle is essential to the conduct of monetary policy independent of the specific form of the Taylor rule. Suppose that $\omega$ was equal to zero, so that the Fed only responded to inflation and not to the output gap. The condition for the Taylor principle would be unchanged.

In order to derive a model which can be estimated, we modify equation (2) in accordance with previous research on the Taylor rule. We consider forward looking Taylor rules, so that the Fed's interest rate target responds to expectations of current and future inflation:

$$
r_{t}^{*}=\mu+(1+\delta) E_{t} \pi_{t+h}+\omega \hat{y}_{t}
$$

where $E_{t} \pi_{t+h}$ is the expectation of the inflation rate at time $t+h$ formed at time $t$. We use the period $t$ expectation of inflation in time $t$, rather than the inflation rate itself, because the inflation rate is not contemporaneously known to policymakers.

Rather than making an instantaneous adjustment of the Federal Funds Rate towards its target level, the Fed tends to smooth changes in the interest rate. As is common practice, we assume 
$\mathrm{AR}(1)$ smoothing, so that the actual Federal Funds Rate $r_{t}$ is the following function of its target level $r_{t}^{*}$ :

$$
r_{t}=(1-\rho) r_{t}^{*}+\rho r_{t-1}+\varepsilon_{t}
$$

where $\rho$ is the degree of smoothing. The more instantaneous the response to the shocks, the more $\rho$ tends to zero. Substituting (3) into (4) and allowing the parameters to switch between the two regimes, we get the following two state specification for the nominal interest rate:

$$
r_{t}=\left(1-\rho_{S_{t}}\right)\left\{\mu_{S_{t}}+\left(1+\delta_{S_{t}}\right) E_{t} \pi_{t+h}+\omega_{S_{t}} \hat{y}_{t}\right\}+\rho_{S_{t}} r_{t-1}+\varepsilon_{t}
$$

The unobserved state variable takes on the values zero or one: $S_{t}=\{0,1\}$. We specify Gaussian innovations, with state dependent variances,

$$
\varepsilon_{t} \sim N\left(0, \sigma_{S_{t}}^{2}\right)
$$

where the unobserved state variable is governed by the following transition probabilities:

$$
\begin{aligned}
& \operatorname{Pr}\left[S_{t}=0 \mid S_{t-1}=0\right]=q \\
& \operatorname{Pr}\left[S_{t}=1 \mid S_{t-1}=1\right]=p .
\end{aligned}
$$

Sims and Zha (2006) argue that if the variance is assumed to be constant, one may find spurious structural change in the slope coefficients in monetary policy rules. We allow the Gaussian errors to be heteroskedastic to sidestep this problem.

\section{Real-Time Data}

Our real time inflation forecasts come from the Greenbook dataset, which is available from the Philadelphia Fed website. ${ }^{4}$ The Greenbook forecasts are published with a five year lag and, as of the writing of this paper, end in 2005:4. We extend the Greenbook forecasts through 2007:4

\footnotetext{
${ }^{4}$ http://www.philadelphiafed.org/econ/forecast/greenbook-data/phila-data-set.cfm
} 
by splicing them with inflation forecasts from the Survey of Professional Forecasters (SPF). ${ }^{5}$ The inflation forecasts are predictions of the annualized quarter-over-quarter growth rate of the GNP/GDP price level. To estimate a Taylor rule, we need year-over-year inflation rate forecasts. We thus transform the Greenbook/SPF data by taking the average of four consecutive quarterover-quarter forecasts. We then have $E_{t} \pi_{t+h}$ for $h=0,1, \ldots, 4$. Since inflation at time $t$ is not available in real time, $h=0$ is a forecast of current inflation, or a "nowcast." It is based on four quarterly forecasts, from $t-3, t-2, t-1$, and $t$, the first three of which are actual realized values of inflation. For $h=2, E_{t} \pi_{t+2}$ is the average of $t+2$ and $t+1$ forecasts, the time $t$ nowcast, and the $t-1$ realized inflation rate. Only the $h=3$ and $h=4$ year-over-year inflation forecasts are based entirely on unrealized values of inflation. The starting dates for the Greenbook inflation forecasts are 1965:4 for $h=0$ and $h=1$ and 1968:4, 1973:2, and 1974:2 for $h=2,3$, and 4 respectively.

For the output gap, we first consider the real-time measure used by Orphanides (2004), which is based on estimates from the Council of Economic Advisors (CEA) and the Commerce Department. Orphanides' data ends in 1995:4. We update the output gap series through 2007:4 using Congressional Budget Office (CBO) real-time estimates and forecasts of potential GDP, published yearly, which we combine with real-time actual GDP to obtain the output gap. We also compute output gaps as percentage deviations from quadratic trends. For these measures, we use real-time GDP data compiled by the Philadelphia Fed. The vintages start in 1965:4 and end in 2007:4, and the data for each vintage starts in 1947:1. For each quarter starting in 1965:4, the real-time output gap is computed as the percentage deviation from trend at the end of the sample, using all data that was available at the time to estimate the trend.

\footnotetext{
${ }^{5}$ http://www.philadelphiafed.org:80/econ/spf/index.cfm
} 


\section{Empirical Results}

We estimate Equation (5) using Hamilton's (1989) algorithm for the nowcast and four forecasts of inflation. We use the average Federal Funds Rate in the final month of the quarter as our nominal interest rate. We allow the constant term, as well as the coefficients on expected inflation and the output gap, the interest rate smoothing parameter, and innovation variance to be regime dependent. We first demonstrate that our estimates from a Markov switching Taylor rule suggest two separate regimes. We then determine that the Taylor rule parameter, $\delta$, in equation (1) is indistinguishable from zero in one of the regimes and significantly positive in another.

Figure 1 plots the Fed Funds Rate, the nowcast of inflation, and the Orphanides/CBO realtime measure of the output gap. The shaded area corresponds with estimating that we are in state zero. ${ }^{6}$ We only provide a figure for the nowcast because the estimated state distributions are consistent across the five inflation forecasts. We estimate what will be seen as the destabilizing Taylor rule state, state zero, occurs from 1973:1 - 1975:1 and again from 1979:4 - 1985:1. State one, a stabilizing Taylor rule state, occurs from the beginning of the sample in 1965:4 through 1972:4, from 1975:2 - 1979:3, and again from 1985:2 through the end of the sample in 2007:4.

The parameter estimates are reported in Table 1. In state zero, the coefficient on inflation, $\hat{\delta}$, is negative for every inflation forecast. The Taylor principle that $(1+\delta)>1$ is clearly not satisfied, as the Fed did not raise the nominal interest rate more than point for point in response to higher inflation forecasts. As shown in Figure 1, there were a number of times when the nominal interest rate fell as inflation rose, which may explain why the estimates of $\delta$ are all negative in state zero, albeit insignificant.

\footnotetext{
${ }^{6}$ We use the typical convention of calling a regime change when the smoothed probabilities cross one-half.
} 
In contrast, state one implies a significant and positive value of $\delta$ for every inflation forecast, suggesting that the Fed followed a stabilizing Taylor rule. The null that the inflation coefficients in both states are the same can be rejected at the $1 \%$ significance level for every inflation forecast horizon. The parameter $\hat{\delta}_{1}$ ranges from 0.80 to 0.94 , which implies that the Fed was keeping inflation in check by increasing the nominal interest rate by almost 2 percentage points when inflation increased by 1 percent.

If we visually divide Figure 1 into three stabilizing (non-shaded) and two non-stabilizing (shaded) periods, the results for three of the five periods seem intuitive. The Taylor principle holds from the beginning of the sample in $1965: 4$ to $1972: 4$, a period of relatively low inflation compared to the rest of the 1970s. Beginning in 1985:2 and lasting through the rest of the sample to 2007:4, we estimate that the Taylor principle held during the time frame of what has come to be permanently lower inflation. The switch to this state accords with the beginning of the Great Moderation. The Taylor principle does not hold from 1973:1 - 1975:1, a period of high inflation including the first oil price shock.

The results for two of the periods might seem less than intuitive at first glance. While monetary policy during the four years preceding Paul Volcker's disinflation is not generally regarded as successful, we estimate that the 1975:2 - 1979:3 period is characterized by a stabilizing Taylor rule state. As shown in Figure 1, the Federal Funds Rate closely tracked the inflation nowcast through 1978:1, and then rose by more than point-for-point through 1979:3. Between 1975:2 and 1978:1, however, the output gap was large and negative. With the output gap exerting downward pressure on the interest rate, tracking the inflation nowcast required the Federal Funds rate to respond more than point-for-point with the inflation nowcast in order to counteract the negative effect from the output gap. 
We also estimate that the Taylor rule was destabilizing from 1979:4 - 1985:1. This is of course the period during which the Fed, under Chairman Paul Volcker, lowered inflation. During this time, the Fed abandoned the targeting of the Federal Funds rate in favor of targeting nonborrowed reserves. ${ }^{7}$ While disinflation occurred through most of the period, this change in the primary instrument of monetary policy resulted in short term nominal interest rates being quite erratic, experiencing both their highest levels and largest volatility. We would surely not expect our estimates to suggest that the Fed was pulling down inflation via the increasing the Fed Funds rate during this period. This empirical finding, however, is in contrast with recent research on estimated Taylor rules. We will return to this in the next section.

The second major component of the Taylor rule is that the Fed raises/lowers the nominal interest rate when the output gap is positive/negative. We find that the response of the interest rate to the output gap across all inflation forecast horizons was larger when the Taylor principle held. In State 1, the coefficient $\hat{\omega}$ ranges from 0.49 to 0.61 while, in State $0, \hat{\omega}$ ranges from 0.40 to 0.57 . In addition, $\hat{\omega}$ is always highly significant in State 1 while, in State $0, \hat{\omega}$ is most often only marginally significant. The difference in significance levels, however, may be driven by low power of the tests in State 0, given the short amount of time spent in that state.

We find that there is much more interest rate smoothing in the stable Taylor rule state. The typical $\hat{\rho}$ in state zero is about 0.5 , compared to around 0.8 when the Fed follows the Taylor principle. Not surprisingly, the estimated innovation standard deviation is about 4 times larger in state zero than in the stable state one. We also report estimates of the implied inflation target $\pi^{*}$. Since the constant term depends on the inflation coefficient, the inflation target, and the equilibrium real interest rate, we assume that the equilibrium real interest rate equals $2.5 \%$ and

\footnotetext{
${ }^{7}$ See Lindsey, Orphanides, and Rasche (2005), and Goodfriend (2007) for further discussion.
} 
back out an implied inflation target using the estimated inflation coefficients. When the Fed was actively targeting inflation via changes in the Federal Funds rate, we get estimates of $\pi^{*}$ between $2.2 \%$ and $2.4 \%$. In contrast, when the Fed does not follow the Taylor principle, the estimates of $\pi^{*}$ range from $21 \%$ to $23 \%$. These numbers are so large that they suggest that the Fed did not have a target level of inflation during those periods.

Taylor (2000) has argued that the real-time CEA output gap estimates from Orphanides (2004) that we utilize in Table 1 were affected by political influence during the 1970s and that neither economic analysts nor policymakers paid serious attention to these estimates. For these reasons, we consider an alternative real-time measure of the output gap based on recursive quadratic detrending, which has become a common method of constructing output gaps for Taylor rules. ${ }^{8}$ For this measure of the gap, the observation at time $t$ uses data up through time $t-$ 1 , so that it is available to the policy maker in real time. ${ }^{9}$

We present our parameter results for the quadratic output gap in Table 2 and Figure 2 plots the Fed Funds rate, output gap, and the nowcast of inflation, again with shaded areas corresponding to $\hat{S}_{t}=0$. The quadratic detrended output gap measures are much smaller than the CEA output gap measures during the recessions of the mid-1970s and early 1980s. The largest negative output gap occurs in 1975 for both measures, but falls from -16.15 percent for the CEA measure to -10.42 percent for the recursive quadratic detrended measure. The same pattern, although with less negative numbers, occurs in 1982 during the trough of the early 1980s

\footnotetext{
${ }^{8}$ While linear detrending was commonly used in the 1970s to measure U.S. postwar output gaps, it is no longer considered an appropriate method of detrending by those who espouse deterministic detrending. Growth rates in the 1950s and 1960s were higher than in the 1970s and afterwards, causing every output gap after 1973 to be negative. Murray and Nelson (2000) raise a similar criticism of linearly detrending output, as it implied that output was continuously falling below trend from 1991-1998.

${ }^{9}$ Cecchetti et al. (2007) and Levin and Taylor (2013) utilize a one-sided Hodrick-Prescott (HP) filtered real-time output gap measure. Nikolsko-Rzhevskyy and Papell (2011) show that this measure produces unreasonably small real-time output gaps for the 1970s, even if the end-of-sample problem is corrected as in Watson (2007)
} 
recession. By 1990, however, the pattern disappears, and the largest negative output gap during 1992 is about the same for both measures.

Despite substantial differences between CEA and quadratic detrended output gap measures, the parameter estimates in Tables 2 convey the same message as in Table 1 . The timing of the state distribution for the Taylor rule is identical between both measures. For every inflation forecast, $\hat{\delta}$ is insignificant in state zero, and positive and significant in state one. As in Table 1, the null that the inflation coefficients in both states are the same can be rejected at the $1 \%$ significance level for every inflation forecast horizon. The point estimates range from 0.75 to 0.80 for $h=0$ through 3 . For $h=4, \hat{\delta}$ is 1.29 . This estimate for the response to inflation is quite high, and the standard error on $\hat{\delta}$ is more than twice as large as the lower horizons, which probably reflects the shorter samples for $h=4 .^{10}$

Turning to the output gap, the results in Table 2 are nearly identical to those in Table 1 for the stabilizing Taylor rule state. The coefficient $\hat{\omega}$ on the output gap ranges from 0.62 to 0.78 and is significant for all inflation forecast horizons. For the destabilizing Taylor rule state, there is no evidence that the Fed responded to the output gap. The coefficient $\hat{\omega}$ is much smaller than in Table 2, ranging from 0.11 to 0.34 , and is never significant. The parameter estimates for the interest rate smoothing coefficient and the innovation standard deviation display no significant differences from Table $1 .^{11}$

\footnotetext{
${ }^{10}$ We also estimated our model with a real time Beveridge-Nelson output gap, where the level of output is assumed to be an ARIMA $(2,1,2)$ as in Morley, Nelson and Zivot (2003). As expected, the sign on the output gap coefficient is negative, since the BN cycle is countercyclical. However, the coefficients are insignificant in both regimes for all 5 inflation horizons. In addition, none of the positive inflation coefficients in State 1 are significant, although we find similar state distributions.

${ }^{11}$ We considered an alternative parameterization which allows the slope coefficients to switch independently of the variance of the error term, as in Banaian and Lo (2011). For our data, the Taylor Principle is estimated to hold for the entire sample, during most of which the response to inflation is estimated to be 4.22 . While the Taylor Principle holding for the entire sample is consistent with Orphanides (2004), the estimated response to inflation in this alternative parameterization is much higher than in any other study that we are aware of.
} 


\section{The View from the Trenches and Beyond}

The most direct comparison of our results is to Orphanides (2004). Using data from 1965:4 to 1995:4, he estimates forward looking Taylor rules for $h=1-4 .{ }^{12}$ He splits the sample into pre and post-Volcker periods, with the change occurring between 1979:2 and 1979:3, and concludes that there was no significant change in the Fed's response to inflation before and after Volcker. In both regimes the Fed was estimated to have followed a stabilizing Taylor rule. The parameter $(1+\delta)$ is estimated to be about 1.5 pre-Volcker and about 2.0 after 1979:3. The one significant change he finds is with respect to the output gap: the Fed responded to deviations of output from its potential before, but not after Volcker became Chair.

Our estimates of the change in the Federal Reserve's response to inflation and the output gap are noticeably different from Orphanides' findings. Orphanides splits his sample after 1979:2. While this is an intuitive break date, it is chosen exogenously and implies only two regimes. Our results suggest that when the break date is endogenized via Markov switching, each of Orphanides' "regimes" contains periods where the Federal Reserve did and did not follow the Taylor principle. We find that not only did the Federal Reserve change their response to inflation throughout the entire sample, but that the timing of these changes in not simply pre and postVolcker. Indeed, for the Volcker years, we conclude that it was not until he had less than two years remaining in his term that monetary policy permanently switched to a stabilizing Taylor rule. This starkly contrasts with the conclusion that $(1+\delta)>1$ for the entire sample, or even for the entire post-Volcker sample. While Orphanides concludes that the response to the output gap is regime dependent, we find that the regime dependence is a function of whether or not the Fed is trying to stabilize inflation, not whether or not Paul Volcker had yet taken office. This

\footnotetext{
${ }^{12}$ He uses AR (2) smoothing in the published version, although AR(1) smoothing in a working paper version leads to the same conclusions.
} 
qualitative conclusion is in accord with the findings of Boivin (2006), Kim and Nelson (2006), and Davig and Leeper (2006, 2011).

To determine if the difference between our results and Orphanides (2004) is due to endogenizing the timing of the regime switches, or merely an artifact of using a larger sample, we re-estimate our Markov switching Taylor rule for Orphanides'sample ending in 1995:4. The parameter estimates are reported in Table 3 and Figure 3 plots the data and estimated state distribution. The estimated dates of the unstable state are identical to those of the full sample. For every inflation forecast, the estimated value of $\delta$ is insignificant in state zero and significant in state one, with $(1+\hat{\delta})$ around 1.5. As in Table 1 , which is identical to Table 3 except for the end date, we find that the output gap coefficient is only significant in the stable Taylor rule state (again with $h=4$ as the exception). Since we are using the exact same data as in Orphanides (2004), we are left with the conclusion that Orphanides' (2004) claim that the Federal Reserve has not changed its response to inflation since 1965 is the result of assuming that the date of a possible regime change coincided with Paul Volcker taking over as Chairman of the Fed.

Davig and Leeper (2006, 2011) estimate a Markov Switching Taylor rule with ex-post data beginning in 1948. They estimate that the postwar period has 4 states: a Taylor rule state with low and high variance errors, and a non Taylor rule state with low and high variance errors. Unlike the other studies cited here, they do not employ interest rate smoothing. In contrast to our results, they find that monetary policy was passive from the beginning of their sample until 1979. Post-Volcker, they estimate that the Taylor principle held, with the exception of 1991-1994 and 2001 to the present. Similar to our results, they find that the response to the output gap was stronger when the Taylor principle is satisfied, although their parameter estimates on the output gap are much smaller than ours. 
We also compare our results to Boivin (2006). He estimates forward looking Taylor rules with real time data, time varying policy coefficients, and heteroskedasticity. In contrast to our framework, he allows the variance of the error terms to change independently of the Taylor rule coefficients, by allowing a one-time break in variance in October 1979. Within this alternative framework, he finds that the Fed's response to inflation changed throughout the 1970s. In the early part of the decade $(1+\hat{\delta})$ was well above unity, fell below unity from 1975 to 1979 , but then rose above unity in 1980 where it remained until the end of his sample. These results differ from both Orphanides' and ours. Boivin's estimated coefficients from 1975-1979 contrasts with our results, which suggest that the Taylor principle was followed during this period. Also in contrast to Boivin, we estimate that the Taylor principle was not followed from the last quarter of 1979 through the first quarter of 1985.

Regarding the output gap, Boivin's results are closer to Orphanides than ours. ${ }^{13} \mathrm{He}$ estimates a gradually decreasing but significantly positive response from 1970 until Volcker's appointment, then a statistically insignificant response until 1986, after which the effect is smaller than the pre-Volcker period but significant. Boivin also allows for two changes (three regimes) in the variance of the policy shock; 1979.10 and 1982.10. His results for the time varying response to inflation and output are qualitatively unchanged.

Kim and Nelson (2006) estimate forward looking Taylor rules with revised data, time varying policy coefficients, with the error variance following a $\operatorname{GARCH}(1,1)$ process. They find that the inflation coefficient is positive during the 1970s, but insignificantly different than one. The response to inflation is greater than one during the 1980s and 1990s, although only significantly so during the 1980 s. They attribute the insignificance of the response to inflation

\footnotetext{
${ }^{13}$ Boivin (2006) uses an unemployment gap which is the difference between unemployment and its estimated natural rate.
} 
during the 1990s to the decreased volatility of inflation, which caused the federal funds rate to be less informative about changes in inflation, widening their confidence intervals. Regarding the output gap, they find that between 1974 and 1979, the response was positive and significant. During the 1980s, the response was insignificant, and beginning in 1991 it became significant for the rest of their sample. ${ }^{14}$

The most significant difference between our results and those of Davig and Leeper (2006, 2011), Boivin (2007), and Kim and Nelson (2006) is the behavior of the estimate of the Fed's response to inflation during the early years of the Volcker period. They find that the response to inflation was not only greater than one and significant, but that the switch to a Taylor Rule state occurred close to the time Volcker took office. In contrast, we do not find that Volker reduced inflation by following a Taylor rule. This is consistent with Volker's answer in 1982 to James Tobin's question of why he didn't lower interest rates to mitigate the rise in unemployment. Volker responded that he did not set the interest rate. He sets the money supply, and the market sets the interest rate. ${ }^{15}$

Due to the model specification and the data used, our econometric modeling framework is more directly comparable to Boivin (2006) than to Kim and Nelson (2006). Time varying parameter and Markov switching models each have advantages and disadvantages. While Boivin's coefficients evolve gradually, ours change immediately with the endogenously determined break dates. We restrict the switches in inflation and output gap coefficients to occur simultaneously, where Boivin does not, but our variance switches are chosen endogenously, whereas Boivin's variance break dates are exogenous. The relative success of these frameworks

\footnotetext{
${ }^{14}$ The differences between our results and Kim and Nelson's (2006) results are driven by both our model and our use of real time data. We estimated our model with revised data using two different vintages (2013Q1 and 2009Q1). We find the same numerical story as when we use real time data, a similar state distribution, but neither the inflation coefficients nor the output gap coefficients are significant in either state.

${ }^{15}$ The conversation is paraphrased in Leeson and Taylor (2012).
} 
is determined by the actual nature, gradual or discrete, of changes on policy. We believe that our framework correctly picks up the 1979-1985 period as being a non-Taylor Rule state because the actual change in monetary policy in late 1979 was discrete.

\section{Conclusions}

We estimate a Markov switching model for various real-time forward looking Taylor rules. The estimated Taylor rule equation switches between states where the Fed does and does not try to stabilize inflation by following the Taylor Principle. In contrast to most previous research, the periods for which the Fed either did or did not follow the Taylor principle are not constrained to coincide with the tenure of different Fed chairmen. In addition to the coefficient on forecasted inflation which determines the Taylor principle, the coefficients on the output gap and the interest rate smoothing parameter, as well as the constant term and the innovation variance, are allowed to be regime dependent.

We find that the Taylor principle holds for 1965:4-1972:4, 1975:2-1979:3, and 1985:22007:4, and does not hold for 1973:1-1975:1 and 1979:4-1985:1. These results are robust across five types of inflation forecasts, from within-quarter nowcasts to one-to-four quarter-ahead forecasts, and two types of real-time output gaps, calculated by the CEA/CBO and constructed by quadratic detrending.

The stable and unstable Taylor rule states exhibit a number of sharp differences. The response of the interest rate to the output gap is larger and more significant, there is much more interest rate smoothing, the implied inflation target is an order of magnitude lower, and the innovation standard deviation is much smaller in the state where the Taylor principle holds.

The pre and post-Volcker subsamples each contain multiple Taylor rule regimes. The Fed followed the Taylor principle from 1966 to 1972 . While rising inflation was of great concern at 
the time, in retrospect it is usually considered a period of low-to-moderate inflation. The Fed did not follow the Taylor principle in 1973 and 1974, a period of high inflation associated with the first oil shock. From 1975 to 1979, a period in which the Fed did not succeed in bringing down inflation, it did attempt to conduct stabilizing policy with respect to inflation forecasts. From 1980 to 1984 , the period in which Volcker did succeed in reducing inflation, it was not by following the Taylor principle. The Fed switched to a stabilizing Taylor rule state at the onset of the Great Moderation in 1985, which has endured to the present. 


\section{References}

Alcidi, Cinzia, Alessandro Flamini, and Andrea Fracasso, 2011, "Policy Regime Changes, Judgment and Taylor rules in the Greenspan Era," Economica 78:89-107.

Banaian, King, and Ming Chien Lo, 2011, "Interpreting U.S. monetary policy using the Taylor rule: A regime-switching approach,” working paper, St. Cloud State University.

Boivin, Jean, 2006. "Has U.S. monetary policy changed? Evidence from drifting coefficients and real-time data" Journal of Money, Credit and Banking, 38: 1149-1179.

Cecchetti, Stephen, Peter Hooper, Bruce Kasman, Kermit Schoenholtz, and Mark Watson, 2007, "Understanding the evolving inflation process," U.S. Monetary Policy Forum.

Clarida, Richard, Jordi Gali, and Mark Gertler, 2000. "Monetary policy rules and macroeconomic stability: Evidence and some theory," Quarterly Journal of Economics, 115: 147-180.

Davig, Troy and Eric Leeper, 2006, "Fluctuating Macro Policies and the Fiscal Theory," in Daron Acemoglu, Kenneth Rogoff, and Michael Woodford eds., NBER Macroeconomics Annual 2006 (Cambridge: MIT Press), 345-377.

Davig, Troy and Eric Leeper, 2011, "Monetary-Fiscal Policy Interactions and Fiscal Stimulus," European Economic Review, 55: 211-227.

Favero, Carlo and Tommaso Monacelli, "Fiscal Policy Rules and Regime (In)Stability: Evidence from the U.S., IGIER Working Paper No. 282, January 2005.

Goodfriend, Marvin, 2007. "How the World Achieved Consensus on Monetary Policy." Journal of Economic Perspectives, 21: 47-68.

Greenspan, Alan, 2004. "Risk and uncertainty in monetary policy," American Economic Review, American Economic Association, 94: 33-40.

Hamilton, James, 1989. "A new approach to the economic analysis of nonstationary time series and the business cycle," Econometrica, 57: 357-384.

Kim, Chang-Jin and Charles Nelson, 2006. "Estimation of a forward-looking monetary policy rule: A time-varying parameter model using ex post data," Journal of Monetary Economics, 53: 1949-1966.

Leeson, Robert and John Taylor, 2012, "In Pursuit of Policy Rules: A Conversation between Robert Leeson and John B. Taylor," in Evan Koenig, Robert Leeson, and George Kahn, eds., The Taylor Rule and the Transformation of Monetary Policy, Hoover Institution Press. 
Levin, Andrew and John Taylor, 2013, "Falling Behind the Curve: A Positive Analysis of Stop-Start Monetary Policies and the Great Inflation," in Michael Bordo and Athanasios Orphanides, eds., The Great Inflation: The Rebirth of Modern Central Banking, University of Chicago Press.

Morley, James, Charles Nelson, and Eric Zivot, 2003, "Why Are Beveridge-Nelson and Unobserved-Component Decompositions of GDP So Different?," The Review of Economics and Statistics, 85(2): 235-243.

Nelson, Edward, 2005, "The Great Inflation of the Seventies: What Really Happened?" Advances in Macroeconomics, Vol. 5(2), 1-48.

Murray, Christian, and Charles Nelson, 2000, "The Uncertain Trend in U.S. GDP," Journal of Monetary Economics 46: 79-95.

Nikolsko-Rzhevskyy, Alex, and David H. Papell, 2011, "Taylor Rules and the Great Inflation," working paper, University of Houston.

Orphanides, Athanasios, 2001. "Monetary policy rules based on real-time data," American Economic Review, 91: 964-985.

Orphanides, Athanasios, 2004. "Monetary policy rules, macroeconomic stability, and inflation: A view from the trenches," Journal of Money, Credit, and Banking, 36: 151-175.

Owyang, Michael and Gary Ramey, 2004, "Regime Switching and Monetary Policy Measurement," Journal of Monetary Economics 51: 1577-1597.

Sims, Christopher and Tao Zha, 2006. "Were there regime switches in U.S monetary policy?" American Economic Review, 96: 54-81.

Taylor, John, 1993. "Discretion versus policy rules in practice," Carnegie-Rochester Conference Series on Public Policy, 39: 195-214.

Taylor, John, 1999. "A historical analysis of monetary policy rules," in John Taylor, ed., Monetary Policy Rules, University of Chicago Press, 319-347.

Taylor, John, 2000. "Comments on Athanasios Orphanides' The quest for prosperity without inflation," unpublished, Stanford University.

Watson, Mark, 2007. "How Accurate are Real-Time Estimates of Output Trends and Gaps," Federal Reserve Bank of Richmond Economic Quarterly, 93: 143-161. 
Table 1. Taylor Rule Estimates with Real-Time Greenbook Output Gaps

$$
r_{t}=\left(1-\rho_{S_{t}}\right)\left\{\mu_{S_{t}}+\left(1+\delta_{S_{t}}\right) E_{t} \pi_{t+h}+\omega_{S_{t}} \hat{y}_{t}\right\}+\rho_{S_{t}} r_{t-1}+\varepsilon_{t}
$$

\begin{tabular}{|c|c|c|c|c|c|c|c|c|c|c|}
\hline & \multicolumn{2}{|c|}{$\mathrm{h}=0$} & \multicolumn{2}{|c|}{$\mathrm{h}=1$} & \multicolumn{2}{|c|}{$\mathrm{h}=2$} & \multicolumn{2}{|c|}{$\mathrm{h}=3$} & \multicolumn{2}{|c|}{$\mathrm{h}=4$} \\
\hline State $S=\{0,1\}$ & 0 & 1 & 0 & 1 & 0 & 1 & 0 & 1 & 0 & 1 \\
\hline Inflation $\delta$ & $\begin{array}{l}-0.39 \\
(0.33)\end{array}$ & $\begin{array}{c}0.86 \\
(0.29)\end{array}$ & $\begin{array}{c}-0.30 \\
(0.34)\end{array}$ & $\begin{array}{c}0.85 \\
(0.23)\end{array}$ & $\begin{array}{l}-0.32 \\
(0.35)\end{array}$ & $\begin{array}{c}0.80 \\
(0.21)\end{array}$ & $\begin{array}{l}-0.47 \\
(0.36)\end{array}$ & $\begin{array}{c}0.85 \\
(0.27)\end{array}$ & $\begin{array}{l}-0.46 \\
(0.39)\end{array}$ & $\begin{array}{c}0.94 \\
(0.26)\end{array}$ \\
\hline Output gap $\omega$ & $\begin{array}{c}0.51 \\
(0.26)\end{array}$ & $\begin{array}{c}0.61 \\
(0.13)\end{array}$ & $\begin{array}{c}0.46 \\
(0.26)\end{array}$ & $\begin{array}{c}0.58 \\
(0.09)\end{array}$ & $\begin{array}{c}0.40 \\
(0.26)\end{array}$ & $\begin{array}{c}0.53 \\
(0.08)\end{array}$ & $\begin{array}{c}0.52 \\
(0.27)\end{array}$ & $\begin{array}{c}0.48 \\
(0.11)\end{array}$ & $\begin{array}{c}0.57 \\
(0.26)\end{array}$ & $\begin{array}{c}0.49 \\
(0.10)\end{array}$ \\
\hline Smoothing $\rho$ & $\begin{array}{c}0.47 \\
(0.16)\end{array}$ & $\begin{array}{c}0.84 \\
(0.04)\end{array}$ & $\begin{array}{c}0.49 \\
(0.15)\end{array}$ & $\begin{array}{c}0.80 \\
(0.05)\end{array}$ & $\begin{array}{c}0.51 \\
(0.14)\end{array}$ & $\begin{array}{c}0.79 \\
(0.04)\end{array}$ & $\begin{array}{c}0.32 \\
(0.20)\end{array}$ & $\begin{array}{c}0.84 \\
(0.04)\end{array}$ & $\begin{array}{c}0.27 \\
(0.20)\end{array}$ & $\begin{array}{c}0.84 \\
(0.04)\end{array}$ \\
\hline St Dev $\sigma$ & $\begin{array}{c}2.40 \\
(0.30)\end{array}$ & $\begin{array}{c}0.57 \\
(0.04)\end{array}$ & $\begin{array}{c}2.33 \\
(0.30)\end{array}$ & $\begin{array}{c}0.54 \\
(0.04)\end{array}$ & $\begin{array}{c}2.32 \\
(0.28)\end{array}$ & $\begin{array}{c}0.52 \\
(0.04)\end{array}$ & $\begin{array}{c}2.46 \\
(0.34)\end{array}$ & $\begin{array}{c}0.49 \\
(0.03)\end{array}$ & $\begin{array}{c}2.48 \\
(0.35)\end{array}$ & $\begin{array}{c}0.49 \\
(0.03)\end{array}$ \\
\hline Const $\mu$ & $\begin{array}{l}10.40 \\
(2.95)\end{array}$ & $\begin{array}{c}0.60 \\
(0.83)\end{array}$ & $\begin{array}{c}9.44 \\
(3.07)\end{array}$ & $\begin{array}{c}0.59 \\
(0.66)\end{array}$ & $\begin{array}{c}9.18 \\
(3.10)\end{array}$ & $\begin{array}{c}0.60 \\
(0.59)\end{array}$ & $\begin{array}{c}11.83 \\
(3.98)\end{array}$ & $\begin{array}{c}0.43 \\
(0.78)\end{array}$ & $\begin{array}{l}12.50 \\
(3.97)\end{array}$ & $\begin{array}{c}0.23 \\
(0.76)\end{array}$ \\
\hline $\mathrm{P}\left[\mathrm{S}_{\mathrm{t}}=\mathrm{i} \mid \mathrm{S}_{\mathrm{t}-1}=\mathrm{i}\right]$ & $\begin{array}{c}0.93 \\
(0.05)\end{array}$ & $\begin{array}{c}0.99 \\
(0.01)\end{array}$ & $\begin{array}{c}0.93 \\
(0.04)\end{array}$ & $\begin{array}{c}0.98 \\
(0.01)\end{array}$ & $\begin{array}{c}0.94 \\
(0.04)\end{array}$ & $\begin{array}{c}0.98 \\
(0.01)\end{array}$ & $\begin{array}{c}0.94 \\
(0.05)\end{array}$ & $\begin{array}{c}0.98 \\
(0.01)\end{array}$ & $\begin{array}{c}0.95 \\
(0.05)\end{array}$ & $\begin{array}{c}0.98 \\
(0.01)\end{array}$ \\
\hline Implied $\pi^{*}$ & 20.52 & 2.22 & 22.85 & 2.26 & 20.83 & 2.36 & 19.95 & 2.43 & 21.98 & 2.42 \\
\hline
\end{tabular}

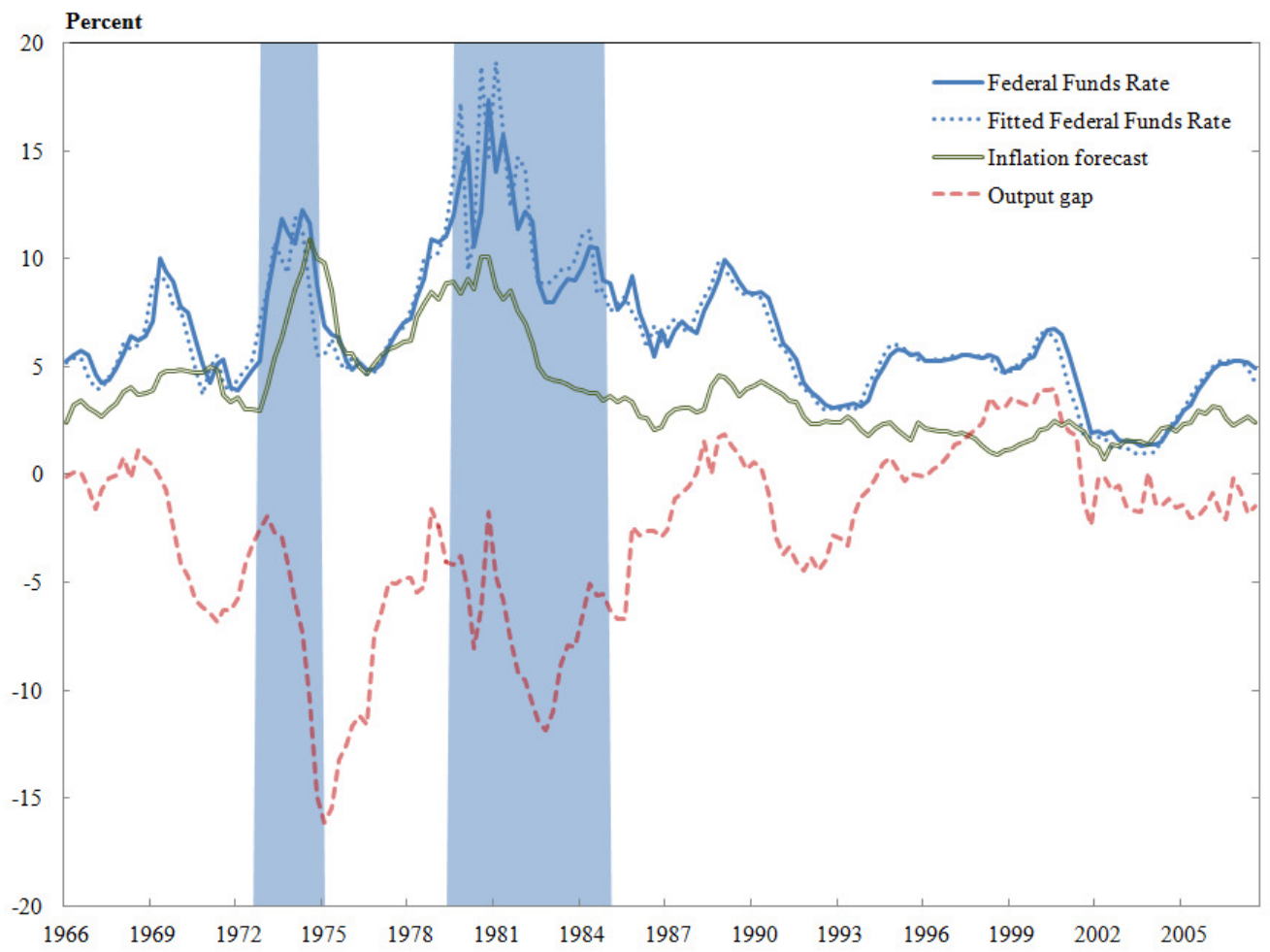

Figure 1. Taylor rule state distributions with the "nowcast" of inflation and real-time Greenbook output gaps estimated over the 1965:4-2007:4 sample 
Table 2. Taylor Rule Estimates with Real-Time Recursive Quadratic Detrended Output Gaps

$$
r_{t}=\left(1-\rho_{S_{t}}\right)\left\{\mu_{S_{t}}+\left(1+\delta_{S_{t}}\right) E_{t} \pi_{t+h}+\omega_{S_{t}} \hat{y}_{t}\right\}+\rho_{S_{t}} r_{t-1}+\varepsilon_{t}
$$

\begin{tabular}{|c|c|c|c|c|c|c|c|c|c|c|}
\hline & \multicolumn{2}{|c|}{$\mathrm{h}=0$} & \multicolumn{2}{|c|}{$\mathrm{h}=1$} & \multicolumn{2}{|c|}{$\mathrm{h}=2$} & \multicolumn{2}{|c|}{$\mathrm{h}=3$} & \multicolumn{2}{|c|}{$\mathrm{h}=4$} \\
\hline State $S=\{0,1\}$ & 0 & 1 & 0 & 1 & 0 & 1 & 0 & 1 & 0 & 1 \\
\hline Inflation $\delta$ & $\begin{array}{l}-0.37 \\
(0.41)\end{array}$ & $\begin{array}{c}0.75 \\
(0.35)\end{array}$ & $\begin{array}{c}-0.27 \\
(0.45)\end{array}$ & $\begin{array}{c}0.80 \\
(0.29)\end{array}$ & $\begin{array}{c}-0.30 \\
(0.46)\end{array}$ & $\begin{array}{c}0.76 \\
(0.26)\end{array}$ & $\begin{array}{l}-0.20 \\
(0.45)\end{array}$ & $\begin{array}{c}0.80 \\
(0.30)\end{array}$ & $\begin{array}{c}0.17 \\
(0.81)\end{array}$ & $\begin{array}{c}1.29 \\
(0.63)\end{array}$ \\
\hline Output gap $\omega$ & $\begin{array}{c}0.34 \\
(0.39)\end{array}$ & $\begin{array}{c}0.78 \\
(0.21)\end{array}$ & $\begin{array}{c}0.26 \\
(0.41)\end{array}$ & $\begin{array}{c}0.78 \\
(0.17)\end{array}$ & $\begin{array}{c}0.23 \\
(0.40)\end{array}$ & $\begin{array}{c}0.71 \\
(0.15)\end{array}$ & $\begin{array}{c}0.18 \\
(0.41)\end{array}$ & $\begin{array}{c}0.67 \\
(0.17)\end{array}$ & $\begin{array}{c}0.11 \\
(0.63)\end{array}$ & $\begin{array}{c}0.62 \\
(0.27)\end{array}$ \\
\hline Smoothing $\rho$ & $\begin{array}{c}0.52 \\
(0.17)\end{array}$ & $\begin{array}{c}0.88 \\
(0.03)\end{array}$ & $\begin{array}{c}0.53 \\
(0.17)\end{array}$ & $\begin{array}{c}0.85 \\
(0.03)\end{array}$ & $\begin{array}{c}0.53 \\
(0.16)\end{array}$ & $\begin{array}{c}0.84 \\
(0.03)\end{array}$ & $\begin{array}{c}0.44 \\
(0.20)\end{array}$ & $\begin{array}{c}0.86 \\
(0.03)\end{array}$ & $\begin{array}{c}0.45 \\
(0.24)\end{array}$ & $\begin{array}{c}0.91 \\
(0.03)\end{array}$ \\
\hline St Dev $\sigma$ & $\begin{array}{c}2.54 \\
(0.33)\end{array}$ & $\begin{array}{c}0.57 \\
(0.04)\end{array}$ & $\begin{array}{c}2.52 \\
(0.32)\end{array}$ & $\begin{array}{c}0.55 \\
(0.04)\end{array}$ & $\begin{array}{c}2.50 \\
(0.32)\end{array}$ & $\begin{array}{c}0.53 \\
(0.04)\end{array}$ & $\begin{array}{c}2.63 \\
(0.36)\end{array}$ & $\begin{array}{c}0.50 \\
(0.03)\end{array}$ & $\begin{array}{c}3.09 \\
(0.56)\end{array}$ & $\begin{array}{c}0.52 \\
(0.04)\end{array}$ \\
\hline Const $\mu$ & $\begin{array}{c}7.74 \\
(2.97)\end{array}$ & $\begin{array}{c}-0.84 \\
(1.29)\end{array}$ & $\begin{array}{c}6.79 \\
(3.57)\end{array}$ & $\begin{array}{l}-0.81 \\
(1.06)\end{array}$ & $\begin{array}{c}7.02 \\
(3.56)\end{array}$ & $\begin{array}{c}-0.69 \\
(0.94)\end{array}$ & $\begin{array}{c}6.58 \\
(3.83)\end{array}$ & $\begin{array}{l}-0.83 \\
(1.07)\end{array}$ & $\begin{array}{c}3.96 \\
(7.16)\end{array}$ & $\begin{array}{l}-1.85 \\
(2.03)\end{array}$ \\
\hline $\mathrm{P}\left[\mathrm{S}_{\mathrm{t}}=\mathrm{i} \mid \mathrm{S}_{\mathrm{t}-1}=\mathrm{i}\right]$ & $\begin{array}{c}0.92 \\
(0.05)\end{array}$ & $\begin{array}{c}0.98 \\
(0.01)\end{array}$ & $\begin{array}{c}0.92 \\
(0.05)\end{array}$ & $\begin{array}{c}0.98 \\
(0.01)\end{array}$ & $\begin{array}{c}0.93 \\
(0.05)\end{array}$ & $\begin{array}{c}0.98 \\
(0.01)\end{array}$ & $\begin{array}{c}0.94 \\
(0.05)\end{array}$ & $\begin{array}{c}0.98 \\
(0.01)\end{array}$ & $\begin{array}{c}0.86 \\
(0.10)\end{array}$ & $\begin{array}{c}0.97 \\
(0.02)\end{array}$ \\
\hline Implied $\pi^{*}$ & 14.08 & 4.45 & 16.08 & 4.14 & 15.15 & 4.19 & 20.61 & 4.19 & -8.56 & 3.38 \\
\hline
\end{tabular}

Notes: The interest rate $r_{t}$ is the average Federal Funds rate for the last month in the quarter. Inflation is defined as the year-over-year GDP deflator growth rate. The Greenbook inflation forecasts starting dates are 1965:4, 1968:3, 1968:4, 1973:3, 1974:2 for inflation forecast horizons $\mathrm{h}=0, \ldots, 4$ respectively. The 2006:12007:4 inflation forecasts come from the Survey of Professional Forecasters. The equilibrium real interest rate is assumed to be $2.5 \%$.

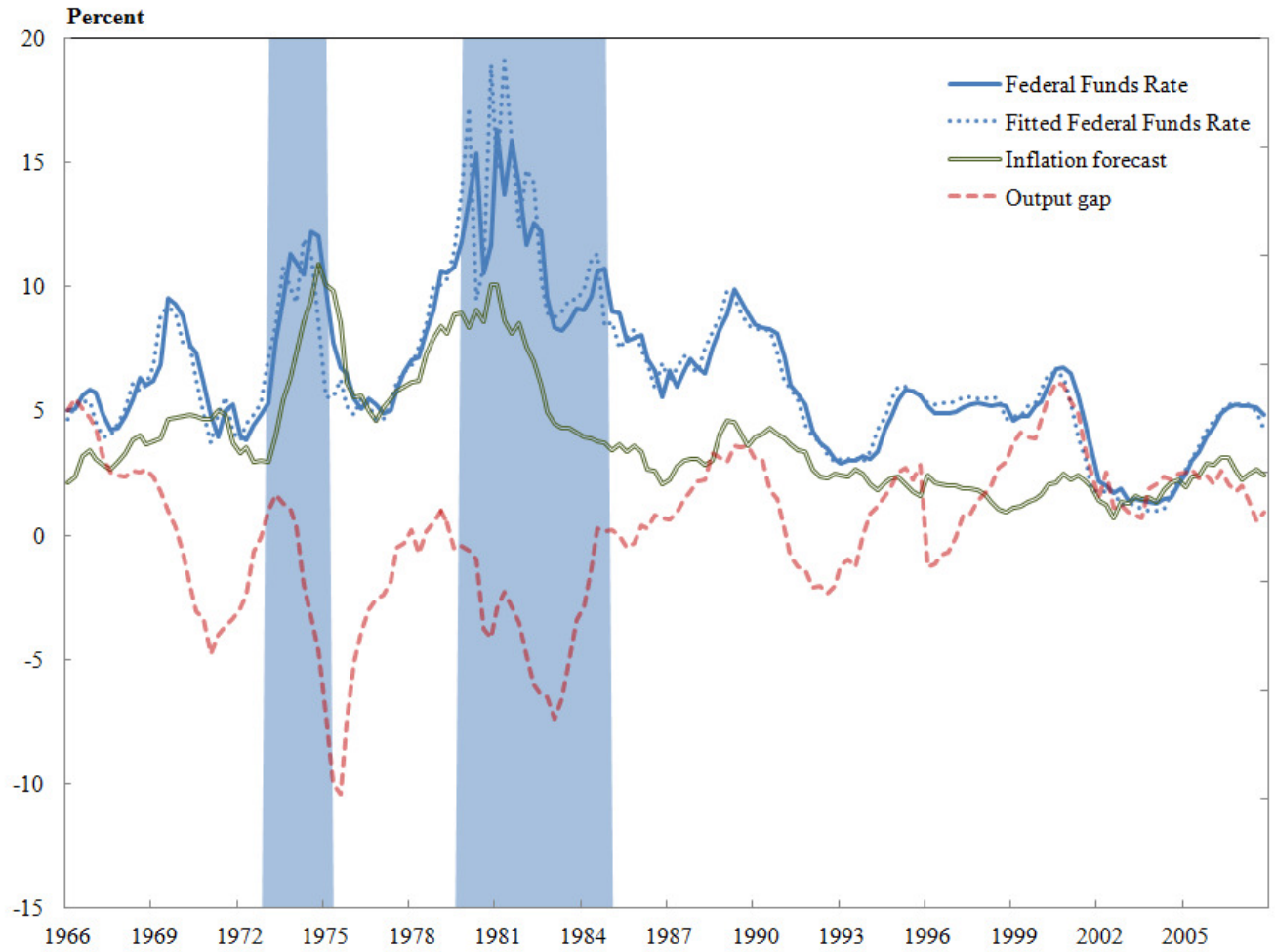

Figure 2. Taylor rule state distributions with the "nowcast" of inflation and recursive quadratic detrended output gaps estimated over the 1965:4-2007:4 sample 
Table 3. Taylor rule estimates with Greenbook real-time output gaps over the 1965:4-1995:4 sample

$$
r_{t}=\left(1-\rho_{S_{t}}\right)\left\{\mu_{S_{t}}+\left(1+\delta_{S_{t}}\right) E_{t} \pi_{t+h}+\omega_{S_{t}} \hat{y}_{t}\right\}+\rho_{S_{t}} r_{t-1}+\varepsilon_{t}
$$

\begin{tabular}{|c|c|c|c|c|c|c|c|c|c|c|}
\hline & \multicolumn{2}{|c|}{$\mathrm{h}=0$} & \multicolumn{2}{|c|}{$\mathrm{h}=1$} & \multicolumn{2}{|c|}{$\mathrm{h}=2$} & \multicolumn{2}{|c|}{$\mathrm{h}=3$} & \multicolumn{2}{|c|}{$\mathrm{h}=4$} \\
\hline State $S=\{0,1\}$ & 0 & 1 & 0 & 1 & 0 & 1 & 0 & 1 & 0 & 1 \\
\hline Inflation $\delta$ & $\begin{array}{l}-0.39 \\
(0.33)\end{array}$ & $\begin{array}{c}0.42 \\
(0.25)\end{array}$ & $\begin{array}{c}-0.30 \\
(0.31)\end{array}$ & $\begin{array}{c}0.37 \\
(0.17)\end{array}$ & $\begin{array}{c}-0.35 \\
(0.35)\end{array}$ & $\begin{array}{c}0.43 \\
(0.19)\end{array}$ & $\begin{array}{l}-0.50 \\
(0.36)\end{array}$ & $\begin{array}{c}0.55 \\
(0.33)\end{array}$ & $\begin{array}{c}-0.24 \\
(0.34)\end{array}$ & $\begin{array}{c}0.53 \\
(0.20)\end{array}$ \\
\hline Output gap $\omega$ & $\begin{array}{c}0.42 \\
(0.26)\end{array}$ & $\begin{array}{c}0.52 \\
(0.26)\end{array}$ & $\begin{array}{c}0.47 \\
(0.25)\end{array}$ & $\begin{array}{c}0.53 \\
(0.07)\end{array}$ & $\begin{array}{c}0.44 \\
(0.25)\end{array}$ & $\begin{array}{c}0.52 \\
(0.09)\end{array}$ & $\begin{array}{c}0.55 \\
(0.27)\end{array}$ & $\begin{array}{c}0.47 \\
(0.12)\end{array}$ & $\begin{array}{c}0.51 \\
(0.21)\end{array}$ & $\begin{array}{c}0.54 \\
(0.09)\end{array}$ \\
\hline Smoothing $\rho$ & $\begin{array}{c}0.46 \\
(0.15)\end{array}$ & $\begin{array}{c}0.78 \\
(0.06)\end{array}$ & $\begin{array}{c}0.48 \\
(0.14)\end{array}$ & $\begin{array}{c}0.70 \\
(0.05)\end{array}$ & $\begin{array}{c}0.50 \\
(0.15)\end{array}$ & $\begin{array}{c}0.71 \\
(0.05)\end{array}$ & $\begin{array}{c}0.30 \\
(0.20)\end{array}$ & $\begin{array}{c}0.82 \\
(0.05)\end{array}$ & $\begin{array}{c}0.36 \\
(0.17)\end{array}$ & $\begin{array}{c}0.74 \\
(0.06)\end{array}$ \\
\hline St Dev $\sigma$ & $\begin{array}{c}2.38 \\
(0.30)\end{array}$ & $\begin{array}{c}0.61 \\
(0.05)\end{array}$ & $\begin{array}{c}2.30 \\
(0.27)\end{array}$ & $\begin{array}{c}0.56 \\
(0.05)\end{array}$ & $\begin{array}{c}2.32 \\
(0.28)\end{array}$ & $\begin{array}{c}0.56 \\
(0.06)\end{array}$ & $\begin{array}{c}2.46 \\
(0.34)\end{array}$ & $\begin{array}{c}0.53 \\
(0.05)\end{array}$ & $\begin{array}{c}2.35 \\
(0.31)\end{array}$ & $\begin{array}{c}0.47 \\
(0.06)\end{array}$ \\
\hline Const $\mu$ & $\begin{array}{l}10.46 \\
(2.96)\end{array}$ & $\begin{array}{c}2.37 \\
(086)\end{array}$ & $\begin{array}{c}9.51 \\
(2.82)\end{array}$ & $\begin{array}{c}2.53 \\
(0.63)\end{array}$ & $\begin{array}{c}9.67 \\
(3.08)\end{array}$ & $\begin{array}{c}2.31 \\
(0.74)\end{array}$ & $\begin{array}{l}12.41 \\
(3.98)\end{array}$ & $\begin{array}{c}1.73 \\
(1.18)\end{array}$ & $\begin{array}{l}10.35 \\
(3.18)\end{array}$ & $\begin{array}{c}1.79 \\
(0.75)\end{array}$ \\
\hline $\mathrm{P}\left[\mathrm{S}_{\mathrm{t}}=\mathrm{i} \mid \mathrm{S}_{\mathrm{t}-1}=\mathrm{i}\right]$ & $\begin{array}{c}0.93 \\
(0.05)\end{array}$ & $\begin{array}{c}0.98 \\
(0.01)\end{array}$ & $\begin{array}{c}0.93 \\
(0.04)\end{array}$ & $\begin{array}{c}0.98 \\
(0.02)\end{array}$ & $\begin{array}{c}0.93 \\
(0.04)\end{array}$ & $\begin{array}{c}0.97 \\
(0.02)\end{array}$ & $\begin{array}{c}0.93 \\
(0.05)\end{array}$ & $\begin{array}{c}0.97 \\
(0.02)\end{array}$ & $\begin{array}{c}0.95 \\
(0.04)\end{array}$ & $\begin{array}{c}0.97 \\
(0.02)\end{array}$ \\
\hline Implied $\pi^{*}$ & 20.51 & 0.30 & 23.33 & -0.08 & 20.63 & 0.46 & 19.68 & 1.37 & 32.32 & 1.33 \\
\hline
\end{tabular}

Notes: The interest rate $r_{t}$ is the average Federal Funds rate for the last month in the quarter. Inflation is defined as the year-over-year GDP deflator growth rate. The Greenbook inflation forecasts starting dates are 1965:4, 1968:3, 1968:4, 1973:3, 1974:2 for inflation forecast horizons $\mathrm{h}=0, \ldots, 4$ respectively. The Greenbook output gap series comes from Orphanides (2004). The equilibrium real interest rate is assumed to be $2.5 \%$.

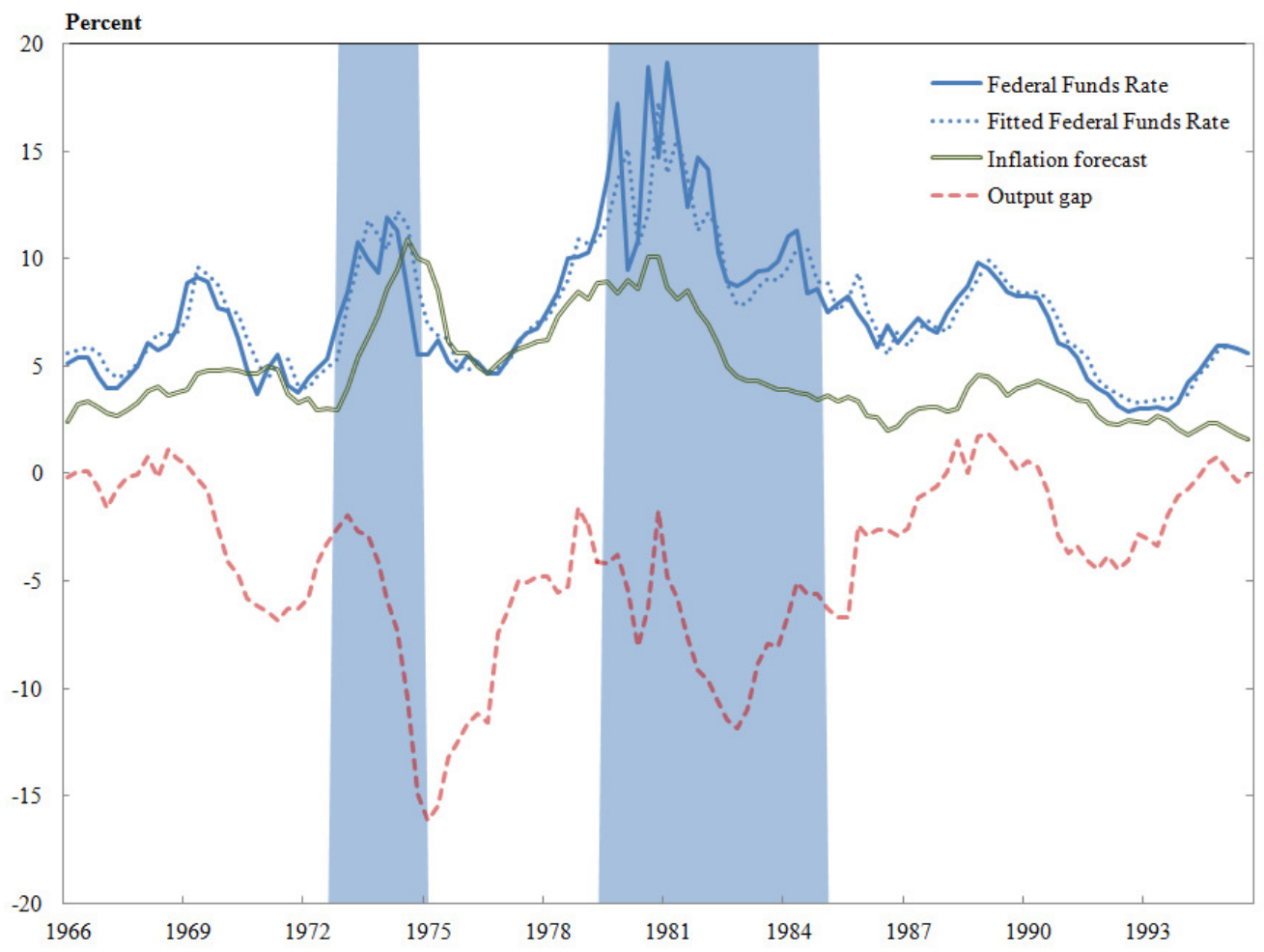

Figure 3. Taylor rule state distributions with the "nowcast" of inflation and real-time Greenbook output gaps estimated over the 1965:4-1995:4 sample 